ON THE

\section{STRUCTURE AND USES}

OF THE

"THYMUS GLAND."

\author{
By Walter Dick, M.D., Glasgow.
}

Tre saying is at least as old as Galen, that there is no part without its nse. As this is generally admitted, and as each succecding discovery in physiology confirms it, we are thereby stimulated to inrestigate the arcana of the animal economy, however small the prospect of success. The uses of the spleen, and the thyroid and thymus glands, are problems on which the ingenuity and taleuts of physiologists hare been long exercised, but hitherto no satisfactory solution of any of them has been adxanced. Some plausible conjectures, it is true, have been entertained regarding the spleen; but any opinions concerning the uses of the thymus gland, which have yet been advanced, are not deserving of serious consideration. Anatomists now generally sum up its physiology, after liaving described its situation and structure, by simply saying, that it serves some unknown purpose during fotal live. Winn we consiner its size, we are naturally led to believe that it must minis ter to some important end. Before entering on the consideration of this subject, I shall premise a few remarks on the structure of the organ in question.

The name, thymus gland, which it has received, implies the belief that it is of a glandular nature, and as such it has been described by all those who have written about it. It is of moment to ascertain if this be really the case, for so long as it is called a gland, or supposed to be of a glandular structure, so long shall we be inclined to the supposition, that nature has formed it to separate from the gencral circulating mass some fluid of importance in the foetal economy. What analogy is there, we may ask, between the thymus and any other gland, conglomerate or conglobate? Is it the granular and cellular appearance which a section of it presents, that leads to the belief of its being a gland? If so, it is an improper ground of belief. For we find the cellular tissue, in the soles of the set and palms of the hands, presenting a similar appearance. I would not be understood to infer from this, that the thymus body is rnerely cellular membrane and fat. Sir Astley Cooper has given a pretty minute description of it; but his description, I am inclined to think, is somewhat biassed by his belief in the glandular nature of this body. If it were a gland, it would certainly have some excretory duct to eliminate its. secretion. No one, however, has ever discovered such a duct, even after the most paticnt and careful examination. Hewson himself, who believed in the glandular structure and function of the thymus, fruitlessly sacrificed many animals in searching for it; and he was equally unsuccessful in his cxaminations in the human subject. Parity of structure does not imply parity of function. If it really possessed an excretory duct we should, a priori, expect, from the size of the organ itself, that it would not be exceedingly small; and when such men as Rysch, and Malpighi, and Mascagni, did not detect it, we may safely conclude that no such duct exists.

"Toutes les glan des ont des conduits," says Bichat, "destinés à rejeter au dehors le fluide qu' elles separent de la masse du sange;" or, "comme ils ne se trouvent que dans les glandes, on doit les considerer avec le tissu propre de ces organes." Since, then, all glands have excretory ducts, we must either admit that the thymus is a solitary exception to the general law above stated, or, that it does not perform the function of a gland. Whether it be more reasonable, or more consistent with facts, to come to the former than to the latter conclusion, I leave others to decide for themselves. I myself have decided in favour of the latter.

If I have proved to my own satisfaction the nox-glandular nature of this 5ohry I surely shall not be accused of jocsunpition in proposing to change its name, from thymus gland, to thymus, simply. For, in anatomy, names are often bestowed upon parts from their supposed uses or structure; and when a name is bestc wed erroneously, as I think that of thymus gland is, by continuing to use the name, we are apt, as $\mathrm{Ma}$ gendie says of another subject, "to give permanence to an opinion which is by no means proved."

The thymus is lodged in the anterior mediastinum. It is in contact anterionly with the sternum, and descends from the lower part of the neck nearly to the diaphragm, heing, in the full-grown fotus, according to Boyer, "tres volumineux," and lying on the left subclavian vein, part of the rrachea, and frort of the pericardium. "Elle present une échancrure qui la divise en deux portions, ou comes, dont la droite est ordmairement plus grosse et plus longue que la gauche. II est rougeât."e et très mou dans le foetus. Les lobules dont ce corps est composé sont creux, et leur cavites communiquent les unes avec les autres. Si l'on fait une certure dans une partie quelconque du thymus il en sort une quantite de suclaiteux, souvent teint de sang; et coagulable par l'alcool." This description, so far as it goes, agrees with Sir Astley Cooper's; but Boyer makes no mention of what that distinguished surgeon calls the reservoir of the thymus.

The opinion I have formed as to its use, 
leads me to think, that the larger it is in the / probable, because we have advanced suff. fœetus, while of natural structure, the respi- cient to render at least questionable, the ration will eventually be the more full and glandular nature of the body, $\rightarrow$ not plansiperfect. The thymus receives its blood ble, because the fluid it is supposed to secrete chiefly from the inferior thyroid and mam- must come from that which it is intended to mary arteries, and returns it into the neigh- dilute; and, consequently, instead of dilut. bouring venous trunks. Its nerves are delicate and difficult of demonstrition, and come from the phrenic and great intercostal.

Numerous lymphatics have been seen by different anatomists ramifying oier its surface. Some have even supposed that these were its excretory ducts. If the lymphatics are more numerous here than elsewhere (which I bclieve is not the case), it is probably because they have been more assicluously sought for: Indeed when men believed that the thymus was a gland, it was necessary for them to believe that its secre. tion must be removed from it somehow or another, and certainly under this impression it was natural enough for them to look upon the lymphatics as performing this office. But if we have shown that the thymus is not a gland, we cannot any longer riew the lymphatics as its excretory ducts, and we need no longer wonder why an excretory duct has not been discovcred belonging to it.

Boyer, who believed in the glandular structure of the thymus, assigus as the reason of its not, like the other glands, possessing an excretory duct, its being " une glande aveugle, d'on il ne sort rien lorsqu' on la presse sans l'avoir ouverte." It is difficult, however, to understand what he means by "une glande aveugle," and to me it appears equivalent to saying, that it is not glandular. For what is the characteristic of a conglo merate gland? Is it not its secerning power, and its possessing a duct to convey from it the finid which it secretes? The thymus bears no resemblance to a conglobate gland; we, thercfore, cannot agree with Boyer, when he says, " On peut donc, le considerer comme une glande conglobée ordinaite, mais d'une texture plus molle."

From what we have premised, I think we may conclude, that the thynus is nota gland, and resembles neither those belonging to the conglomerate nor conglobate class, but is an organ sui generis, and of a cellnlar structure, and, as dissection shows ns, readily undergoes the process of absorption soon after birth.

We will now state some of the opinions that have been entertained respecting the uses of the thymus. Heister, when speaking of this subject, says, "Forte lympliam secernit, eamque per vasa lymphatica ductui thoracico infundit. pro sanguinis et chyli dilutione, secuti glandula mesen'eica et pancreas agumt in diluendo chylo. Major huic usus est in non natis, quam in natis: quia illi respiratione adhue destituantur, a quo tenuitas sanguinis mavime procuratur." The use here assigned to the thymus is, I think, neither probable, nor plausible,-iming it would rather tend to inspissate the blood.

Bellingeri supposed that the thymus was formed to prepare during fotal life a liquid, for the nourishment of the child, which he supposed was carried to its mouth by several ducts, which of course his fancy rather de. picted, than his eyes ever saw. It appears to me, indeed, impossible for one organ or system of organs, to render the blood of the inother more nourishing for the child in utero; and consequently the use just men. tioned appears to me, to say the least of it, a work of supererogation. We nere astonished to find Sir Astley Cooper entertain. ing this opinion. He says,-_" As the thy mus secretes all the parts of the blood, viz, albumen, fibrin, and particles, is it not pro. bable that the gland is designed to prepare a fluid, well fitted for fotal growth and nourishment, from the blood of the mother before the birth of the foetus, and consequently before chyle is formed from food; and this continues for a short time after birth, the quantity of fluid sccreted from the thymus gradually declining, as that of chylification becomes perfectly established?" Hewson supposed that the thymus co-operated with the spleen in the production of the red glo. bules of the blood. Surely this also is a work of supererogation. For do not the globules circulating in the vessels of the foetus come directly from the blood of the mother? Every view, then, which has been taken of the functions of the thymus, is, in my opinion, unsatisfactory and incorrect; and the almost universal opinion now is, that its use or uses, whatever they may be, are unknown. "Les usages du thymus," says M. Boyer, "ne sont point connu, mais son urilité quelle qu'elle soit est plus grand dans le foetus que dans les adultes."

I shall attempt to show that it is formed in the foetus, to be of mo:e service after birth than before it.

Anatomists and others are in the halit of speaking of the carities of the chest and abdomen, which, as Mr. J. Bell shows, is, strictly speaking, erroneous. There is no vacuity in either of those regions, every point being accurate!y filled up by its contained viscera, and no cavity or empty space existing, till formed by disease or accident. some may thinls that in the child in utero, there are parts which might have been left with advantage unoccupied. One of these, perhaps. would be the front of the chest. But the child being subject to the influence of atmospheric pressure, this conld not be the case, and consequently that part must have been filled up by the luag, or, as nature has 
done, by the thymus. It appears to me that if the lungs had occupied, during intra-uterine life, the place of the thymus, there would be too little room for the expansion of the lungs, consilering the density of their texture before they have been permeated by air; in fact, there would have been a useless expenditure of lung, - a circumstance we cannot expect to be effecterl by nature, who is ever perfect in her operations.

When the child is separated from the mother, respiration is established, to enable it to maintain an independent state of existence. Nature seems anxious to have this function as verfect as possible, by diminishing the size of the chest of the child in utero, by the position of the child. and the great size of the thymus and the liver.

We have already spoken of the size of the thymus in the full-grown foetus. The liver at that period is very large, receiving a great supply of blood from the umbilical vein; but after birth, this supply being cut off, it very soon begins to diminish in bulk. It is erident that as both the thymus and liver decrease, the capacity of the thorax will be increased. I know that Tiedemann and Gmelin have made it appear probable that the liver of the foetus is large, and receires a large supply of blood, in order that the blood may undergo a process of decarbonization. This may be, but I think nature also intended it to co-operate with the thymus, in rendering respiration more perfect, by shinking after birth.

In taking a glance at man in infancy, childhood, and adult age, we see, in the first of these periods, a tender, feeble creature, incapable of making almost any exertion of his voluntary muscles, with a quick respiration and hurried pulse. We see him again in childhood, not quite so delicate, exercising with tolerable freedom his locomotive organs, yet incapable of any great or prolonged physical effort. His respiration not so rapid and pulse less quick. When he attains adult age we find him a very different creature. We see him now performing great bodily cfforts, and that for a considerable time. His respiration and pulse are far below, in point of frequency, what they formerly were. In the first of these periods of life we find the size of the chest considerably encroached upon, and the free play of the lungs interiered with, by the thymus and liver, and consequently the respiration is hurried. In process of time the thymus all but disap. pears, and the liver gradually attains that size which nature has assigned it. With these changes the respiration becomes slower, and of course more perfect.

A little reflection will show us that the extent of the pulmonary tissue is less, and that less air (comparatively speaking) is inhaled in to the lungs of a very young child than in more advanced age. A little further reflection will perhaps convince us that this results from the presence of the thymus. As the subject grows older, his movements become more extensive and frequent, and consequently there is more necessity for a free supply of air, and how could this have been afforded better than by the mechanism which I think nature has employed, viz., by forming the thymus large in the early period of life, so that by its shrinking, when riecessity requires it, a greater surface of lung may be afforded for the permeation of air and purification of the blood?

We know that when the thymus, in place of becoming absorbed, continues through life, or becomes diseased, it gives rise to dyspnoea.

It may be asked, What is the cause of this body shrinking or becoming absorbed? We might anwer by asking, How does the ductus arteriosus, or the foramen ovale of the heart, become obliterated? We understand why they become so, but we are ignorant of the how. The absorption of the thymus, however, results chiefly, I think, from the pressure of the lungs against it during respiration. Boyer says, "Cette compression devient tres manifeste, lorqu'one pousse de l'air dans les poumons.'

Glasgow, April 1836.

\section{MILKY APPEARANCE OF THE BLOOD.}

Antoine Gorta, of Cremona, a dealer in lemonade, aged 47 , stout, and muscular, and addicted to wine, became indisposed the next day after a debauch. He was received into the hospital of the town on the $22 \mathrm{nd}$ of May, and showed the following symptoms : -Violent fever; pulse hard and intermitting; constrained respiration, without cough, expectoration, or pain of the region of the heart. He was unable to lie either upon the back or the sides: tumid abdomen; costiveness; scarcity of urine; the inferior extremities odematous; general prostration of strength. The whole skin was pale, particularly that of the face. Blood-letting was prescribed, and a dose of oleum ricini was given.

The next day, viz. the 23rd, the blood appeared as white as milk, and the crassamentum was as purely white as the serum. These two substances could not be distinguished from each other, except by their consistence and fluidity. It is necessary to remark that the blood did not exhale the odour of milk. This blood was reserved for analysis. The same symptoms presented themselves in the patient to-day as yesterday, generally speaking, except that there was more debility of the system. He was again bled, and a dozen of leeches were ap- 